Modern Asian Studies 55, I (202I) pp. I-39. (C) The Author(s) 2020. This is an Open Access article, distributed under the terms of the Creative Commons Attribution licence (http:// creativecommons.org/licenses/by/4.o/), which permits unrestricted re-use, distribution, and reproduction in any medium, provided the original work is properly cited. doi:I0.1017/Soo26749Xigooor8o First published online i m March 2020

\title{
Within and Beyond Modernity: Lived experiences and ethical interruptions of the Tablighi Famaat in West Bengal*
}

\author{
FERNANDE W. POOL \\ Institute of Social Studies, Erasmus University Rotterdam \\ Email:pool@iss.nl
}

\begin{abstract}
This article examines the implications of the growing presence of the Tablighi Jamaat in Joygram, a Muslim-majority village in rural West Bengal, India, drawing on fieldwork conducted between 20II and 20I3. The analysis of reformist Islam as a moral regeneration movement embedded in dharma and catalysing an alternative modernity contributes to the scholarship on lived experiences of Islam, modernity, and ethics. The Tablighi Jamaat in Joygram gains popularity in a political economic context of moral degradation and marginalization, which inspires engagements with globally resonant modern and anti-modern models of the self enveloped in the practice, discourse, and performance of Islamic reformism. These models mutually interact and conflict with locally particular practices and exclusionary categorizations. On the village level, the drive towards modernity ensues in conflicts over moral personhood and social exchanges. On the societal level, the modern aspirations of Joygrami Tablighis go beyond piety to 'good culture' and respected citizenship, and are embedded in anti-modern critiques of the hegemonic categorizations of the secular nation-state by which they are nevertheless confined. It is suggested that reformist Islam should not be misunderstood as pre-modern, anti-secular, or secular, but might better be called 'post-secular' because it encompasses those ideologies in vernacularized forms on the basis of a different ideal conception of society. Islamic reformism in Joygram may resonate with moral regeneration and reactionary movements elsewhere. This analysis of the Tablighi Jamaat demonstrates the potential challenges social movements face in the transition to alternative modernities.
\end{abstract}

* The article draws on ethnographic fieldwork undertaken between October 20II and August 2013. 


\section{Introduction}

The presence of the Tablighi Jamaat (TJ) in West Bengal, India, has been limited until recent decades, but is rapidly growing. ${ }^{1}$ In the early 20 ios an increasing number of young men in Joygram - a Muslim-majority village in West Bengal - were joining the Tablighi Jamaat, a transnational Islamic missionary movement of lay preachers that was founded in 1927 by alumni of the Darul Uloom Deoband Islamic seminary in northern India. The reformist Deobandi school of thought subsequently spread through its vastly expanding network of madrasas and the $\mathrm{TJ}$ to all countries where Muslims live. ${ }^{2}$ Joygrami men and women who do not themselves become members are nonetheless influenced by Da'wa (proselytization) via frequently organized gatherings. In Joygram, the imams in local mosques are Deobandi, the local madrasas follow the Deobandi curriculum, and the Jamiat Ulema-e-Hind, a Deobandi organization of Islamic scholars, frequently organizes gatherings, including sermons. ${ }^{3}$

Reformist Islam is, at times, presented as the 'antimodern antithesis' to liberal secularism (Deeb 2006: 4). This is not only a misrepresentation of reformist Islam but also rests on a simplistic notion of modernity as secularity, and an equally simplistic definition of the latter: a decreasing relevance of religion, first in the public sphere and, eventually, also in the private sphere. Although the TJ does express critiques of modernity, the reality is more complex.

This article proposes an analysis of Islamic reformism through the lens of ethics because it avoids a narrow focus on piety. Instead, it allows for a wide variety of values and moral models, with sources in- and outside of religion, to play a role. Moreover, an ethnography of ethics does not assume people's obedience to a static set of rules but rather unveils the complex negotiations of conflicting moral demands and active

${ }^{1}$ I was told in interviews and conversations (with TJ participants, Deobandi maulānās, and ordinary Muslims) that the TJ and the Deoband had hardly any public presence until the Ig8os. Since then, many Bengali Muslims have gradually converted from Barelwi to Deobandi Islam.

${ }^{2}$ For more on the Tablighi Jamaaat, Deoband, and its madrasas, see Ahmad 2009; Gupta 2009; Masud 2000a; Metcalf ig89; Sikand 2002.

${ }^{3} \mathrm{I}$ refer to those Joygramis who explicitly call themselves Deobandi, who dress accordingly, and who explicitly reflect on their Islamic practice in line with the reformist doctrine, including both lay Muslims and clergy, as 'reformists' or 'Deobandi'. 'Tablighis' are involved with the Tablighi Jamaat and are Deobandis by implication. Furthermore, I focus in this article on male Muslim Joygramis, since it is almost exclusively men who are explicitly Deobandi reformists or Tablighi Jamaat participants. 
construction of normative subjectivities (see also Keane 20I5; Laidlaw 20I4; Lambek 20I0).

Ironically, the Tablighi Jamaat itself performs aspects of the modernity it challenges. The result is friction on both sides: with other villagers insofar as it is modern, and with the state, or a global hegemony of modernity, insofar as it is 'anti-modern'. Exploring the presence of the TJ in Joygram, where its influence is currently expanding, can offer interesting insights into the multifaceted aspirations and controversial positionality of reformist Muslims and contribute to the scholarship on lived experiences of Islam and modernity. Before commencing with a detailed discussion of the theoretical context, the next section will situate the ethnographic research (201 $\left.\mathrm{I}^{-2 \mathrm{OI}}\right)$ in the concrete historical and political context.

\section{Contextualizing Islamic reformism in Joygram}

The partition of Bengal in the wake of Indian independence from the British empire left 6o million Muslims behind on the Indian side to form a minority of 'second-class citizens' (Jalais 2010: I64). The marginalized Muslims consented that to live safely meant proclaiming 'allegiance to India, to communal harmony and to secularism' (Chatterji 2007: I72). The coming to power of the Left Front (a coalition of communist parties) in West Bengal in 1977 did not structurally change bhadralok (upper caste Hindu 'gentlefolk') superiority, despite its discourse of radical leftism focused on the annihilation of class (Chatterjee 2009). In the initial years of the regime, the Left Front successfully improved the conditions of poor and middle-class peasants and daily labourers, but the homogeneous hegemony of the bhadralok combined with communist politics in fact resulted in the central paradox that, despite the intense politicization of society, communal marginalization was depoliticized (favouring class politics) and structural violence against minorities tacitly reproduced (Chatterjee 2009; see Sachar Committee 2006).

The Deoband madrasas and the Tablighi Jamaat were, from the outset, projects to protect a distinctive Muslim identity in a British colony with a Hindu-majority, but the vulnerable minority status of Muslims required a certain quietism. ${ }^{4}$ In the early 20 Ios, when Muslims made up i4 per cent

\footnotetext{
${ }^{4}$ See footnote 2 .
} 
of the population, ${ }^{5}$ Deobandi organizations still felt the need to repeatedly proclaim their loyalty to the Indian nation ${ }^{6}$ - perhaps even more so given the context of growing support for the Hindu-nationalist Bharatiya Janata Party. ${ }^{7}$ However, the de jure availability of welfare schemes did instil a sense of entitlement to the bare bones of modern development (cf. Hansen 1999). There was hope, at least among Joygrami Deobandis, that their moral reforms would help them attain the respectability of 'first-class citizens', while the participation of fellow Muslims in a solidary network helped them cope with their exclusion. Muslims' increasing awareness of political self-determination stands in a complex mutual relation to the rise of the Trinamul Congress (TMC) and its identity politics. The TMC defeated the Left Front in 20I w with populist identity politics that capitalized on the unabated deprivation of Muslims, emboldening them to develop a stronger identity and political voice. ${ }^{8}$

The narrative of the 'decay of public life' is common throughout India (Hansen 1999: 57) and was particularly strong in West Bengal in the direct aftermath of TMC triumph. Joygrami Muslims claimed that the Left Front had rejected dharma, and that its revival could restore order. Dharma is a term usually associated with Hinduism, but in common

${ }^{5}$ Census of 20II Available at: http://censusindia.gov.in/201 Icensus/Religion_PCA. html, [accessed 25 February 2020].

${ }^{6}$ In neighbouring Muslim-majority Pakistan and Bangladesh, more overtly political Islamic and Islamist organizations gained more traction than in India, partly because they were banned in India and partly because, for most Indian Muslims, secular democracy has been too integral a part of political life to be questioned (Ahmad 2009: II; for Pakistan, see Iqtidar 20II; for Bangladesh, see Huq 2009, Shehabuddin 2008; for Sri Lanka, see Haniffa 2008; cf. Osella and Osella 2013).

${ }^{7}$ The BJP won the 2014 general elections under the leadership of Narendra Modi.

${ }^{8}$ The TMC's identity politics and the reintroduction of communal language in West Bengal have also allowed for the popularity of the Hindu-nationalist BJP to spill over into West Bengal in the years following my fieldwork, as I learned during research into the national elections in West Bengal in 2014 (Pool 2016). Since 2013, communal riots have become more common in West Bengal (whereas in previous years most violence was related to party politics). During a visit to Joygram in 2016 I was told about communal riots in a neighbouring village, which were unknown in the area in 20I-2013. Communal relations in the village remain good, possibly because of the majority position of Muslims in Joygram. Promises by the TMC to improve the Muslims' situation were still felt to be mainly empty, and often failed to be realized due to continued corruption. Meanwhile, the TJ continued to grow in popularity in 2016, partly in contradistinction to the increasingly negative public discourse on Muslims by the BJP, and partly because of the continued spread of supposedly 'purer' forms of Islam. 
Bengali parlance it denotes a holistic ethics of justice and order that any human being is expected to enjoy by virtue of being human, whether Hindu, Muslim, or otherwise.

One cannot, however, locate oneself outside the narrative of moral decay: when corruption has seeped into every corner of society, engagements with the immoral environment are inevitable. This elicited a particular sense of individual responsibility from Muslims in Joygram and elsewhere (Das 2010: 242), and the official discourse of the TJ was that a better society starts with improving oneself. There was ample complaint (among Muslim Joygramis) that Muslims just wanted to farm rather than progress; that those Muslims who were educated were 'Hindu-ized' and had forgotten Islam; that Muslim boys worked as gunmen because they just wanted money; and, generally, that they lived up to the stereotype of being ' $b a d m \bar{a} s$ (scoundrels). It was, at least in part, considered the fault of Muslims themselves that the bhadralok still ruled West Bengal and that they suffered from violence and exclusion. This narrative always had the same conclusion: Bengali Muslims 'are very far from Islam', especially the 'stupid' (boka $)$ people visiting the shrine. ${ }^{9}$ This was due to a previous lack of Islamic seminaries and the absence of the TJ. In contrast, the Deoband seminary, which instructs and spreads the 'real Islam' (sathik Isläm), was founded in northern India. So Bengali Muslims needed to be reminded of the proper ethics and the ritual practices of Islam. It was in this context that Islamic reformism, heralded by the TJ, gained widespread popularity.

\section{The (anti)modern ethics of the Tablighi Jamaat: theoretical context}

In Joygram, Islamic reformism found expression in ways that emerged out of particular local virtue ethics that merged Islamic theology and practice with South Asian ideas of being and sociality. It revolved around a generation of dynamic related persons, through ritual and everyday

\footnotetext{
9 'Hindu-ization' and religious illiteracy are very common tropes among Muslim reformers in South Asia. Cf. Ahmad 2009; Ahmad and Reifeld 2004; Huq 2009; Shehabuddin 2008. It might be particularly strong in West Bengal, where Muslims are poor and badly educated relative to Bengali Hindus and to Muslims elsewhere in India (Sachar Committee 2006); where most Muslims are descendants of converts (Eaton I996); and where there is a history of syncretic religious practice. For the colonial roots of opposition between the 'proper' Arab Muslims and Bengali Muslims, see Ahmed (I98I).
} 
bio-moral exchanges, was informed by the political and economic environment of post-communist West Bengal and secular India, and resonated with globally circulating models of modernity. Various moral models have become encompassed within dharma. The semantic and aesthetic expression of the multifaceted dharma in this case was Islamic, because Joygrami Muslims were essentialized in the Muslim jāti (community) from birth and continuously throughout their lifetime. ${ }^{10}$ So, Islamic reformism was a reform within dharma - and any such reform touches upon fundamental moral ideas of what constitutes a person and how one relates to others. Indeed, one of the reasons the turn to reformism created considerable moral unrest among my participants is because the project of Islamic reformism is not limited to religious reform, but is a holistic, all-encompassing moral regeneration project which involves a profound reconfiguration of being in the world.

Some aspects of this moral regeneration project are modern, some are anti-modern. Modernity here does not chiefly refer to historical, political, and economic developments. ${ }^{11}$ Instead, I primarily refer to sets of normative attitudes, values, and subjectivities that underpin, drive, and result from these developments, especially those encapsulated in secularism and liberalism. Secularism refers at once to a political ideology (the separation of religious and worldly powers, nondiscrimination on the basis of religion, and the management of religious difference) and an epistemological and moral position (the valuation of belief-independent rationality; privatization and decrease of religiosity; and the rejection of tradition, the sacred, and the transcendent in favour of empirical evidence, logic, and the immanent). Secularism is deeply interwoven with the values of social liberalism (equality, individual freedom, tolerance, and plurality) and economic liberalism (free market economy and individual [property] rights).

\footnotetext{
${ }^{10}$ As a result of the secular logic of the Indian nation-state and local cosmogonic ideas. See Pool 2016.

${ }^{11}$ Key among which are industrialization and technological innovation, and the rise of (commodity) capitalism, (colonial) nation-states, and mass democratization. Other chief developments include: the upsurge of the social sciences as the backbone of (technocratic) policy and bureaucracy, the ordering of society in separate domains (public domains of politics and the economy; private domains of religion and the family), the measurement of well-being as economic growth, and the globalization of culture and aesthetic representation in self-reflective performance rather than ritual symbolism.
} 
Although these sets of values are the chief reference point, modernity is not a singular, static, and coherent project - and neither is Islam. Across the world 'multiple modernities' (Eisenstadt 2000) have emerged in a mutually transformative interaction with local normativities and globally circulating normative imaginaries (Taylor 2004). ${ }^{12}$ The historical processes that came to fruition in the West in the eighteenth and nineteenth centuries had vernacular origins elsewhere and blended with Western imports via colonial administrations, such as in British India, resulting in particular (post)-colonial modernities (see, for example, Cohn I987; Dirks 200I).

Nevertheless, globally we can observe two elements that are core to the project of modernity: self-determination and self-making (the right - and duty - to be true to oneself, including moral responsibility), and inner conviction (embodying immanence, individualism, and authenticity). ${ }^{13}$ These are key elements in Islamic reformism as practised in Joygram. The idea of inner conviction is well captured in Hansen's (2009) notion of 'cool passion', which I employ as an 'ideal-type' lens to explore the modern in Joygram. Hansen (2009: 2) traces the development of a modern 'political theology of conviction' and argues that the ideal of a proper self 'equipped with interiority and conviction' has become a globally influential model. The ethics of conviction requires transcendence of the lower self and expunging of the unreflective traditions of the past, to acquire 'purer ... more interiorized and more reflexive modalities of belief, religious practice, political aspiration and cultural sensibility' in order to become modern individuals guided by 'well-defined and purified cultural, moral or religious principles' (ibid.: 20). As such, the notion of 'cool passion' captures very well what it means to be modern, without assuming a particular kind of secularity as absence of religion. Whereas in many modernization theories, religion appears as a tradition that chains one to a pre-modern way of

${ }^{12}$ The work on modernity, piety movements, and Islamist organizations in Cairo (Mahmood 2005; Hirschkind 2006), Lebanon (Deeb 2006), Bangladesh (Huq 2008, 2009; Shehabuddin 2008), and Pakistan (Iqtidar 20II; Jamal 2013) demonstrates that the kind of modernity which arises from public piety has vernacular origins and meanings, and is indigenously produced rather than a weaker copy of Western modernity. Similarly, studies of participation in and the influence of the TJ have highlighted alternative modes of globalization (Noor 2014), cosmopolitanism (Horstmann 2007), secularity (Metcalf 2003) as well as new modes of religiosity (Janson 2013) and intimate relationships (White 2012).

${ }^{13}$ My understanding of these terms draws on a wide range of literature, including: Asad 2003; Berman I982; Giddens I990; Keane 2007; Mahmood 2005; Milbank and Pabst 20ı6; Stacey 2018; Taylor 1989, 2004 . 
life, Islamic reformism can be a catalyst for the modern ethics of conviction, not unlike secular modernization projects.

Because self-realization and inner conviction are often reflected in Islamic reformism, as well as other modern aspects - a view of Islam as a religious 'system'; a high degree of rationalization; a rejection of past authorities; a new emphasis on human will; growing individualism; and privatization - it is sometimes called essentially modern as opposed to anti-modern (see, for example, Robinson 2008). ${ }^{14}$ But the Joygrami experience suggests that this is still an incomplete interpretation as reformism also expresses a critique of modernity.

Joygramis express a desire for moral regeneration with explicit reference to the drawbacks of modern liberty and individualism: greed-driven party politics, an exploitative market economy, and a malfunctioning secularism that allows for discrimination against minorities. Deobandi reformists in Joygram draw on a macrocosmic notion of dharma which defies a separation of society into moral (religious) and morally neutral (political and economic) spheres, and seeks to revive morality in private and public life as a whole. They defy the (mis)rule of reason with a re-enchantment of transcendence in all aspects of life and an embodied virtue ethics.

These anti-modern sentiments resonate with Comaroff's (2008) discussion of 'uncool' passion, in a critical evaluation of Hansen's 'cool passion'. Across the globe, she observes a 'rejection of the cool passion of modern reason' (ibid.: 3), expressed in a 'hankering for transcendent imperatives' and a yearning 'for a theologico-politics that can inspire a bloodless world with sublime conviction' (ibid.: 9). This 'anti-modernist' revival expresses 'a discomfort with secular notions of society, politics and morally-neutral public life, a desire to erase the line between the metaphysical and the mundane' (ibid.: 4). An analysis of Islamic reformism in Joygram would not be complete without also attending to the 'anti-modernist' aspects so poignantly described by Comaroff. The discussion of globally circulating models of modern and anti-modern selfhood, as captured in 'cool' and 'uncool' passions, are useful as a heuristic lens through which to explore the idiosyncrasies of Joygram and to draw out particular points of tension.

The first part of the article will discuss the life trajectories of three Deobandi reformists in Joygram. It then turns to changes in aesthetics and performance. Next, the article focuses on two instances in which

${ }^{14}$ See also, for example, Ahmad 2009; Eickelman i992; Eickelman and Anderson I999; Eickelman and Piscatori i996; Jamal 2013; Starrett 1998. 
tensions surfaced between the urge to reform and customary practices or alternative modes of modernization, and discusses these tensions as reflecting an instance of 'extraordinary ethics'. The last section examines the lack of a shared logic between the Indian nation-state and Islamic reformism. The failure of the Indian state to live up to the secular ideals of the modern state has resulted in a limited depoliticized space for navigation for Muslims reified in a pre-modern culturalreligious community. Therefore, there has emerged a paradoxical tension between the piety movement's own objectification of Islam (as a religion that is the source of ethics) and the logic of categorization of the ambiguously secular nation-state, on the one hand, and Joygrami reformists' aspirations for both holistic ethical renewal and inclusion in the nation-state, on the other hand.

\section{Trajectories to conviction: three Joyrami Islamic reformists}

The following life stories of three Joygrami men-Masiruddin, Wahed, and Faizul - trace their motivations for being drawn to the material and ideological environment, and tease out both local particularities and global resonances. These stories exemplify that the aspirations of active TJ participants in Joygram were a complex combination of 'cool' and 'uncool' passions: of modern, global forms of reflexive, interiorized conviction with a postmodern desire to imbue public life with morality and mystical transcendence. These life trajectories reflect individual variability and pragmatic, situational motivations, and demonstrate that the shared inculcation of an embodied, pious conviction does not negate the fact that Joygrami Muslims engage with reformist Islam in much more ambiguous and ambivalent ways than some studies of the TJ suggest (see, for instance, the studies in Masud 2000a-but see also Horstmann 2007). However, underlying the idiosyncrasies, the remarkable congruence in the modus operandi of the $\mathrm{TJ}$ across the world reveals shared modes of conviction and models of personhood, into which these individual stories can give insights. ${ }^{15}$ For instance, in their sermons, the TJ encouraged a move away from text- and rule-based, externally enforced morality to an embodied ethics that

${ }^{15}$ From South Asia (Metcalf 1993; Siddiqi 2012; White 2012) via Southeast Asia (Horstmann 2007; Noor 2014), and Africa (Ahmed 2008; Janson 2013) to Europe and North America (see Masud 2000a; Pieri 2015). 
unites this world and the afterlife in an all-encompassing moral order (cf. Ali 2003: 180); salvation would only follow from virtuous behaviour in this world. The emphasis was on physical, social orthopraxy rather than intellectual orthodoxy based only upon texts (cf. Janson 2013: II). The following narratives show how Joygrami Tablighis tried to embody the Sunnah (Prophet's tradition) in their embrace of an Islam that was highly affective and sensory, challenging a fully interiorized, modern sense of self in their performance of virtue. Another aspect that unites the three 'narratives of becoming' is a sense of moral failure or void, in which conviction arrives as a 'miracle of truth' in a time of darkness, a 'turning point that enables one to become a full person' (Hansen 2009: I4; cf. Comaroff 2008: 3), not unlike Tablighis' narratives in Gambia (Janson 2013: 264) or Pentecostal testimonies in the United States (Luhrmann 2012).

Although I focus here predominantly on male Tablighis, I include the only two Joygrami women who actively participated in the TJ. The Tablighis' transitions to reformism were often looked upon by other Joygramis with a wary scepticism, as not everyone held a coherent reformist Islamic theology. So although I can positively assert that every Muslim in Joygram was influenced by reformism to some extent, and most were consciously aware of the changes in ritual practices and Islamic doctrine, the ways in which these changes affected ordinary life did not go uncontested, as will be discussed in later sections of this article.

\section{Masiruddin Khadim}

Masiruddin Khadim $^{16}$ was a relatively wealthy businessman in his early thirties who lived in Joygram, a village in West Bengal. The Khadims, the largest extended family in Joygram, were the 'caretakers' (musualis) of land now used for a large cattle market just outside Joygram, which covered approximately 600 bigh $\bar{a}$ (200 acres). The land was donated to the Khadims by a Hindu landlord (jamidär) whose child had allegedly been cured by Champa Bibi, who is buried in the shrine on this land. Abu Bakr Khadim, Masiruddin's father, was the caretaker of this shrine which was frequented by Muslims and Hindus alike. ${ }^{17}$ Although

\footnotetext{
${ }^{16}$ All names, including place names, are pseudonyms, except for the names of well-known public figures (such as Siddiqullah Chowdhury Saheb) and well-known places (for example, Delhi).

${ }^{17}$ The property was listed under the State WAQF Board in I899. WAQF properties are inalienable endowments of the Muslim community, to be used for charitable or religious
} 
Masiruddin was of the caretaker lineage, his family ran a part of the cattle market independently and he also worked as a contractor. He was not actively involved with any political party but was a prominent presence at important political events and closely followed the news regarding Siddiqullah Chowdhury Saheb's political party, the All India United Democratic Front (AIUDF).

Masiruddin was a vocal proponent of the Deobandi reformist Islam and an occasional participant in the Tablighi Jamaat. One day I asked Masiruddin to tell me why he converted to reformist Islam and joined the Tablighi Jamaat. He explained that he had been an ordinary boy, Muslim by name, but not giving Islam much thought. He had been living the 'Iffestyle' and although he was a bit embarrassed about his previously un-Islamic lifestyle, he showed me pictures of that time with a big smile on this face. Like many rural boys aspiring to urban masculinity, he had the pictures taken in a studio, wearing a transparent shirt, tight jeans, large sunglasses, and a clean-shaven chin.

At some point in his twenties, Masiruddin started on a quest for ethical guidance: despite how exciting his life was, he felt a moral void. Inspired by his Hindu friends he started to read the Hindu scriptures, and afterwards the Christian Bible. But he came to the realization that the Qur'an, directly given by Allah, provided the most complete system for life, both scientific and ethical, and that he had to follow the 'right path' and immerse himself in Islam. Masiruddin spent four months at the global headquarters of the Tablighi Jamaat in Delhi and changed his lifestyle: he started wearing a white kurta and an untrimmed beard under a shaven upper lip, prayed five times a day, fasted during Ramadan, and attended all important local Islamic congregations. He became interested in the scientific value of the lessons of the Qur'an and the Hadith, rationalizing the logic of self-discipline and the associated aesthetics, and came to believe that the Qur'an is the original source of bijñann (science). ${ }^{18}$

purposes, and have to provide official accounts to the State WAQF Board. The Khadim's WAQF property included the shrine, the graveyard $(m \bar{a} j \bar{a} r)$, the land used for the cattle market and a banyan tree plantation, and the Idgah (enclosed space for prayer on auspicious Islamic days).

${ }^{18}$ Rationality is not an end in itself, as Huq (2008: 462) equally observes for a women's study circle in Bangladesh, but 'a mere modality for facilitating the formation of a scripted Islamic pious-revivalist personhood and public'. But whereas in Muslim-majority Bangladesh the performance of rational pious personhood was in turn part of a larger political project of the Jamaat-i-Islami to secure power, in Muslim-minority India, the 
Masiruddin considered shrine worship as one of the greatest sins and refused to follow in his father's footsteps as a caretaker. He continued, however, to work as a contractor and to be involved in local patronage, appearing on political stages. For Masiruddin, these practices were not anathema to his strong belief that Islam is a 'total way of life', as he would say. In fact, his re-evaluation of Islamic ethics and aesthetics not only provided him with the techniques for self-cultivation but also with a morally higher status in the marketplace and the political landscape.

Masiruddin firmly believed that a better society begins with individuals becoming better people. For this reason, he spoke very highly of the Islamic mission schools. The most important and distinguishing aspect of these private boarding schools - the first of which emerged in Howrah in 1986 - is not the curriculum but the strict regimen and discipline, and the seamless inculcation of an Islamic disposition within the larger project of the making of a modern Muslim middle class. ${ }^{19}$ For Masiruddin, it was important that mission education would not only benefit Muslims, but the entire country. 'The Muslims lag behind, and thanks to the mission schools they will "rise up" (piche theke uthe yāy). India is a democratic country, and I am a part of this country, so if I study better, if I can do a government job $(c \bar{a} k r r)$ well, then that's good for all of India. Muslims can't lag behind.'

Masiruddin in particular also glorified Al Qaeda and the Taliban as the most peaceful people in the world, living examples of Muslims struggling to follow the right path against the evil infiltrations of (Western) capitalism and consumerism. But at the same time, to participate in the liberal democracy of India, he felt it was vital to distance himself from the pervasive image of the 'bad' or disloyal Muslim. Masiruddin deeply lamented the suspicion around, and stereotypes of, Muslims, in both India and other parts of the world, and wanted to demonstrate that Islam is peaceful and that Muslims, if they follow Islam properly, would foster peace instead of violence.

more humble and individualized aim with regard to the state was to gain inclusive citizenship.

${ }^{19}$ The Islamic Mission School in Howrah was founded under the name Al Ameen Mission School, which now has 32 branches across West Bengal. In Joygram, a branch of a similar institution, the $\mathrm{Al}$ Hilal Mission School, was opened in 2013. Al Ameen and Al Hilal mission schools are each managed by a board of private members, usually middle-class Muslim men from Kolkata. The schools follow the curriculum of the West Bengal Board of Secondary Education complemented with a minimum of Islamic subjects. See also Gupta 2009: I26-I66. 
The first time I met Masiruddin's brother Wahed, he had a charismatic appearance, in his clean white pāñjābi (white trousers) and white tupi, with an untrimmed beard and hair growing down the back of his neck. His charisma grew as he told me about the TJ with visceral enthusiasm. His father Abu Bakr, in a locally unusual, green version of the Islamic dress, also with long hair and a grey goatee, seemed to listen to him in a similar subdued manner, as I did. When I asked Abu Bakr whether he participated in the TJ as well, his answer was, '[No], I stay at the shrine (āstāna $)^{\prime}$, and they showed me a dusty picture of a colourful tomb-like structure with him posing in front of it. Wahed's smile suddenly became uncomfortable. It was soon clear to me that this household, with the guardian of a saint's tomb and two TJ participants living under the same roof, was the exemplary microcosm of the larger ethical transitions taking place in Joygram.

Wahed had been one of the first to join the TJ in Joygram, some eight years previously. He said he had felt inspired by the TJ to 'uplift' the morally backward Muslims in West Bengal after an encounter with a group of travelling preachers visiting a nearby village. Together with a young day labourer called Ibrahim, he was the driving force behind the TJ's activities in Joygram. In his daily life, Wahed was primarily preoccupied with the paddy fields and he spent his Saturdays in the office at the cattle market, but his involvement with the TJ and the outings were gradually taking up more of his time. During my ig months in the village, he went twice on a four-month tour to Delhi, every month for three days to nearby villages, and a few times for 40 days to villages in other districts in West Bengal. As he was probably the wealthiest of the regular participants, he acted as a patron: whenever groups of Tablighis from other villages visited Joygram, he took care of most of the expense of feeding them and his house was the place where meals were prepared. He greatly enjoyed the solidarity among the Tablighis, as well as the Da'wa (proselytization) itself. He was a passionate speaker and an austere teacher of reform to the other villagers, which was not always appreciated.

His wife Pompa also participated in the TJ; she went for two three-day tours during my stay (in contrast to Masiruddin's wife, who worked as a nurse and barely covered her hair). Pompa showed a genuine interest in learning the Hadith, and spent her rare spare time reading it. I increasingly overheard her passing on to other women in the hamlet what she had learned on the outings, with a newly gained confidence. Whereas previously she had barely left the house (and, in fact, grew 
up in the house opposite it), meeting only relatives and the occasional neighbour, she now engaged in an international network of women, which filled her with awe. She was one of the first women to wear a burqa when going outside of the hamlet, a new phenomenon in this area.

Wahed applied for a place at the Al-Hilal Mission School in Joygram for his eldest daughter, long before its doors were open. His youngest daughter would attend the girls' madrasa that had recently opened in a nearby village. He had great plans for his only son: he would be highly educated both in Islamic as well as in general subjects, so that he would succeed in life, but most of all, so that he could spread Islam across the world, since he would be fluent in both Arabic and English.

Initially, Wahed was enthusiastically congenial towards me. Although his hospitality and friendliness never dwindled, he increasingly adopted the 'proper' Islamic attitude of distance towards women: he no longer came to sit next to me and avoided eye contact and jocular chit-chat. In public in particular he hardly acknowledged my presence, initially apologetically, but increasingly more sternly. In our continuing conversations about Islam, he increasingly emphasized the centrality of imān (belief) and the afterlife. It was not only towards me that his attitude changed. After another three-day meeting with the TJ, he entered his home with the formal 'Salaam Aleikum' greeting, eliciting a giggling response from his wife. This formality recreated traditional gender relations in multiple ways: by injecting appropriate distance in an intimate relationship, but also enacting equal respect, as the TJ taught him that men and women are fundamentally equal in God's eyes. Wahed lectured Pompa on the Hadith and scolded his father for singing Arabic verses without knowing their meaning. He became ever more aware of Islamic aesthetics and whereas Masiruddin would continue to occasionally wear jeans or a shirt, Wahed only dressed in a white pānjāabi.

\section{Faizul Mondal}

Faizul had an altogether different story. He used to be professional dancer and appeared in music videos. The work required him to go to Mumbai and Delhi, and other major Indian cities. He kept all the pictures and even his shiny clothes in a box and, like Masiruddin, he seemed proud of his previous achievements. He also used to run a dance school in Barakpur, where he met and fell in love with his wife Titli, a girl from Farukhbazar who had attended boarding school in Barakpur. 
Despite the pride he could not hide, he told me he felt he was living a sinful life. One night when he was back in Joygram, just three months before I arrived in the village, he had visited the graveyard $(m \bar{a} j \bar{a} r)$ beside the shrine and the cattle market. An angel had appeared to him who told him that he should stop living his sinful life and follow the right path to Allah. So, in Faizul's case, the 'miracle of truth' was indeed a miracle and involved surrendering to sacred authority.

Faizul immediately gave up the dancing job and moved back to the small mud house in Joygram he had inherited from his mother. He started wearing a tupi (skullcap) at all times, and jocularly introduced himself to me as 'tupioy $\bar{a} l \vec{a}$ ' ('the man with the tupi') on our first encounter. His disposition and behaviour changed radically over the next ig months. Initially, he did not cease to passionately tell me about the virtues of Islam and expand on the teachings of the Prophet Muhammad. After his initial four months with the TJ in Delhi, however, his disposition became increasingly sober and pious, even though the flicker of passion in his eyes never dwindled. Like Wahed, his greetings became more solemn and 'properly' Islamic. At the same time, he became more involved in the cattle market, where he had been doing odd jobs, and he transformed from a jumpy village boy to a respectable businessman. He remained extremely friendly and hospitable, and continued to teach me about Islam whenever I visited him, but there was less of our youthful banter. His 'uncool' passion, inspired by the revelation of the angel, gradually changed into a cool passion of conviction. Notably, the 'darkness' from which Masiruddin and Faizul emerged was the modernity of globalized culture and conspicuous consumption which they had come to reject, instead becoming enveloped in an alternative modernity infused with Islamic and local moral precepts.

Meanwhile, Titli rapidly grew from an adolescent girl into a pious adult, who appeared to cherish her purdah like no other woman. She was very happy Faizul had become a dedicated Muslim. His previous glamorous cosmopolitan lifestyle had inspired in her a fear that he would meet other girls but now she felt she could trust him. She had started a Bachelor's degree but did not seem to like it or care much about it. She was happy at home, she said, although she deeply enjoyed the occasional outings she undertook with the TJ.

Titli was at the forefront of some young Joygrami women who used Islamic reformist discourse to challenge certain norms that undermined their freedoms and rights. For instance, they would call 
the norm that women were not allowed to go to the bazaar a 'cultural' tradition that men invented to suppress women, as men and women were supposed to have equal rights in Islam. According to Titli, the introduction of the niqab was a religious instruction that women chose to follow because it deepened their personal relationship with God. ${ }^{20}$

\section{The Tablighis' challenge to modernity}

These three narratives exemplify the aspiration of reformist Muslims for a kind of sublime conviction that is highly rationalized and purified, but that is equally embodied and mystical: an 'enchanted modern' (Deeb 2006). The conviction and practice of the reformist Muslims in Joygram combine modern and anti-modern elements in a radical alternative, in which the sacred and the emotional, and the rational and the logical are inseparably bound. Reason is sacred, and the sacred is logical. In going beyond the stock categories of secular modernity, Islamic reformism in Joygram heralds an ethical framework for being in the world that does not correspond to, and cannot be contained within, the hegemonic ideologies of our time. Much like other highly emotive social movements within and outside Islam, this nonconformity can cause considerable perplexity and conflict with the representatives of hegemonic frameworks. But, equally, it can cause scepticism and tension on the part of those whom the reformers seek to bring into their fold, and it is to this that I now turn.

\section{Changing aesthetics among Joygrami Tablighis: performing virtue}

One of the most obvious and visible changes that could be observed in Joygram was the changing aesthetics involved with the 'conversion' to reformist Islam. Here, I discuss how Tablighis performed a modern

${ }^{20}$ Cf. Huq (2008, 2009) for similar observations among women in Islamist Qur'anic study groups in Bangladesh. Huq (2009) demonstrates that women also use the lessons learned to challenge received wisdom. A point of difference is that Titli and Pompa primarily received lessons orally and were therefore not in a similar position to question authority on the basis of written text. 
ethical self through their aesthetics, and the scepticism this provoked, which possibly points to a public perception that ascetic withdrawal from the world is the 'end of ethics' rather than the moral high ground.

It was quite a sight to see a troop of $\mathrm{TJ}$ practitioners process through the village. They would walk briskly, usually dressed meticulously in long white pāñäbi and a variety of tupis (skullcaps), with their upper lips shaven and their beards waving, as is the prescribed aesthetic of the Deoband. They would have stern looks on their faces, gazes averted. ${ }^{21}$ Their appearance was one of cleanliness and aesthetic awareness, and contrasted starkly with the usual dress of agricultural labourers: a lingi and a vest. ${ }^{22}$

Several times I found Faizul in his room working on his appearance. He would iron his kurta with the utmost care and he would not leave a single hair on his upper lip. He had brought a waistcoat and a green scarf from Delhi, and he had a way of wrapping the scarf around his head that made him look particularly charismatic. ${ }^{23}$ When I announced that I would be visiting the TJ's 'world market', as Joygramis called the headquarters in Delhi, he was quick to ask me to bring him a tupi as the one he had bought had discoloured.

Small adjustments to dress may make someone look 'closer to Islam' as one tries to emulate the aesthetics of the Prophet Muhammad. To wear a specific 'scent', for instance, is sunnā: I had already noticed that madrasa teachers and Islamic scholars would always carry a minuscule bottle of scent with them, and it became increasingly popular among the TJ participants, too. ${ }^{24}$ Wahed's sudden and abundant use of scent was the object of great mockery by his father. The application of black kohl

${ }^{21}$ When meeting them in groups, even comprised of those with whom I was close, in the confines of their houses, I could not expect more than a stern 'Salaam Aleikum', if I was lucky.

${ }^{22}$ A lungi is a waistcloth, usually stitched to form a large tube of cloth. Joygrami Muslim men usually wear a blue checked lungi, with a white vest.

${ }^{23}$ The turban is reminiscent of a practice at the Deoband madrasa in the early twentieth century, where the best students would be honoured by having a turban wrapped around their heads (Metcalf ig89).

${ }^{24}$ The small bottles often have Arabic text on them and are considered better if they are imported from an Islamic country, preferably Saudi Arabia. Arifuddin, a young madrasa teacher, asked me whenever I went to Delhi to bring him scent; even though the same scents were available locally, he considered the brands available in Delhi to be more properly Islamic. It is fairly uncommon for ordinary villagers to wear any scent, except for the body spray (deodorant) that is slowly becoming popular among the more 
(kājal) on the lower eyelid is another sunna . The Prophet prescribed the application of kohl because it makes the eye-white appear brighter and the eyesight as strong and clear as an eagle's. The young men seemed to be well aware that the black line under their eyes in combination with the long white dresses made their appearance even more charismatic.

To follow the Sunnah closely sometimes meant compromising on previous aesthetic preferences. Soon after coming back from a short tour with the TJ, Wahed suddenly cut his hair, which had curled well down the back of his head and had closely resembled his father's hairstyle. He said it had not been right to wear his hair long, and since he had learned from the TJ to follow the Prophet's exemplary behaviour, he had cut his hair short. I later learned from Samsuddin, an Islamic scholar, that one's haircut was a crucial and very precise matter. It had to be the same length on all sides of the head; for a young Muslim it should preferably be between one and two centimetres long. Only an older, learned scholar had the right to wear his hair long, so Wahed's hairstyle was not only a failure to obey the Sunnah closely, but also a sign of vanity and pretension.

Some women also changed their appearance to be 'close to Islam', substituting the sari (now called a Hindu dress) for the salwar kameez ('real' Muslim attire). The women who participated in the TJ, Pompa and Titli, were at the forefront of making such changes. Pompa complained to me that having to exchange her nightgown for a salwar kameez in the morning, and again before prayer at noon, increased the already heavy burden of laundry, which was done by hand. But apart from that, both women preferred the more practical salwar kameez over the sari, and now they could justify this choice by referring to the official Deobandi discourse, which also stated that it covers the body better than the sari does. Other young women also mobilized this discourse to justify their reluctance to wear a sari, although they admitted to being equally motivated by the increased mobility the salwar kameez offers: cycling to school and work in a sari is tough.

Following on from the above, I suggest that the aesthetics of the $\mathrm{TJ}$ is a multivocal symbol that can be interpreted and also employed in various ways, depending on the actor and the audience. First, the ironed white dress can be a symbol of status as it distinguishes one from the tillers of the soil. Secondly, the body and these aesthetics of dress can be

'modern'/urban-influenced youth. Body spray and scent are considered to be two entirely different things. 
employed as a technique for cultivating the inner self and revealing its potentiality (Mahmood 2005: I66), since dress has performative force (Tarlo and Moors 2013) and is constitutive of the self (Miller 20I0). By dressing like the Prophet Muhammad, one commits oneself to the self-discipline involved in behaving like the Prophet. Initially, Wahed would display a hesitant smile when making use of specifically Islamic (and non-Bengali but Urdu or Arabic) terms and gestures (eliciting a mocking smirk from his wife). Over the course of my fieldwork, however, he gained confidence and lost his initial insecure hesitation; he seemed to have internalized the values that were initially exterior performances.

Mahmood's (2005) interpretation of the exterior performance as a means to transform the interior self applies to some Tablighis, but it is not the entire explanation. So, finally, the public performance of piety and authenticity itself can be the end of aesthetics. I found resonance with Grosso's (2013: 249) observation that 'in Tunis, performance [of ethical personhood] appears to be oriented towards cultivating social relationships and towards maintaining the impression of morality in an atmosphere marked by the fear of moral breakdown', an analysis that is particularly appropriate for Masiruddin.

Although many aspects of Masiruddin's lifestyle changed, he continued to do the same work and for this, being a Tablighi has almost become a useful asset to him. This was especially so in the contractor business, which was commonly assumed to be corrupt: contractors were viewed as immoral, greedy people out to fill their own pockets. Being a businessman and contractor who walked around in sunglasses and transparent shirts would have made it very easy for others to consider him to be badmāś. It was much better for his social status, and as such for his economic opportunities, to look like a dedicated Muslim. His aesthetics almost seemed to give him an a priori protection from critique. Hardly anyone dared to openly talk to me about business or would do so with an apologetic expression on their faces. Masiruddin, instead, jocularly expounded on the shady aspects of obtaining a tender, adding self-evidently, 'well, that's how business goes' (eț to byab's $\bar{a}$ ). $\mathrm{He}$ was himself critical of the corrupt political and economic environment, but he admitted that being drawn into it was inescapable. So, while going about business as usual, his participation in the TJ gave him a sense of dignity and respect, while performing respectability in the public eye. Masiruddin seemed to be aware of the performativity of his aesthetics: he would sometimes greet me with a flat hand by his face (a 'proper' Islamic greeting but locally a very unusual gesture) but could 
never avoid a self-mocking smile. That is not to deny the sincerity of his commitment; he did actively try to cultivate a virtuous character. However, his aesthetics also allowed him to partake in capitalist practices with moral pretence, reminiscent of Weberian Protestants.

For Joygrami Tablighis and devout Deobandis, the 'public' comprises the Muslims in the village, among whom one acts as an exemplary figure, as well as other Muslims and non-Muslims in the wider public sphere. The public performance in turn impacts on self-cultivation: now one has to act according to the criteria the performance establishes. The performance, however, is not always convincing.

\section{The ascetics of the renouncer and the sincerity of the householder}

The sincerity of the Tablighis and devout Deobandis in Joygram was questioned: tropes of irony and mockery were very common in Joygram, and the Tablighis were not spared. The Tablighi's attitude was considered by some to be condescending and pretentious, with too much importance attributed to aesthetic performance rather than to an actual Islamic lifestyle. It was somewhat common to refer to the supposedly pious ones as nāmājis (roughly translatable as 'those who pray a lot') or as dārioyāla or tupioyāla ('he who wears a beard', 'he who wears a tupi, with sarcastic undertones). Rafiq, who claimed to be a committed Muslim but did not seem to find it at all problematic that he occasionally drank alcohol, met girls, and was involved in various dubious businesses, one day said to me: 'Those ... nāmājis ... many just show off ... they don't do it sincerely. Does anyone really pray? Nobody does.' With undisguised sarcasm he commented on the transformation of the boss of the cattle market after his hajj to Mecca: everyone knew he was a corrupt exploiter, 'but now he has become good ... tupi, beard...' I exclaimed in feigned surprise: 'So those who go on Haj and wear tupis and beards are the ones who are most badmās!' He laughed, nodding his head, 'yes, now you got it...'.

Hussain was also critical about TJ participants being 'very nāmājà who are pious 'show off' (dekhānor janya) yet fail to apply the lessons of Islam in everyday life. The small house belonging to Hussain's family was right next to Wahed's house, and one day one of Wahed's regular labourers came to Hussain crying. He had been working all day for Wahed, but he had not been given any food, not even a cup of tea, he complained. I overheard Hussain grumbling, 'he is working with the [Tablighi] 
Jamaat, but in his own house he doesn't care for people'. It may well have been that Wahed had been punishing the labourer on that day, as he was obviously very drunk. Nevertheless, Hussain immediately took the opportunity to see an incongruity between the public performance of piety and the lack of actual virtuous behaviour.

Curiously, Wahed was more often the object of scepticism than Masiruddin. Many Joygramis considered Wahed to be somewhat good, considering his Islamic lifestyle and appearance, but his sincerity in his relations to other villagers was doubted. Masiruddin was considered 'good in every aspect'. The differences between the brothers are reminiscent of the 'householder's dilemma' (see, for example, Burghart I983; Laidlaw I995; Madan I982). Householders are inevitably embroiled in sinful worldly activities to ensure their survival, so it is impossible to attain the goal of moral perfection. A renouncer dedicates his or her life to the sublime Truth and is considered closer to salvation. Both Wahed and Masiruddin were caught in an 'inner conflict' (Parry 1994: 270) of how to balance religious conviction with the demands of everyday life, but Wahed was closer to the path of the renouncer whereas Masiruddin was closer to that of the householder.

The Joygramis' scepticism points to a recognition of the limits of ethics in everyday life. This is what Das (2014) has called 'the difficulty of reality'. Most Tablighis, not unlike the Jains described by Laidlaw (I995), would admit that the goal of emulating the Prophet's exemplary behaviour was impossible, and that they themselves were only 'more or less good Muslims' (motāmōti bhälo Muslim). In the villagers' praise for Masiruddin and scorn of Wahed, there seems to be a recognition that the moral predicament of the householder is more difficult than the renouncer's and hence more praiseworthy: 'that it is not because the renouncer's otherworldly aspirations are impossible for the householder to follow (they are), but that it is inhabiting the world, sustaining it, that is seen as the ethically much more difficult task' (Das 20I4: 488-489). The Joygramis' complaints call into question the value of the modern performance of piety and is a reminder that one is ultimately not the liberated individual of the modern narrative but intimately tied to various social institutions, for better or worse.

\section{Challenges to village ethics: withdrawal from exchange}

Many young men and women in Joygram were drawn to the TJ in an attempt to recover their autonomy and dignity in the face of 
politico-economic marginalization. However, in reacting against the unethical practices in their environment, they also gained autonomy from the bio-moral exchanges in the village. Therefore, the purification of Islam from un-Islamic elements has far-reaching consequences for ethical practice. In this section, I examine how even though Joygrami virtue ethics could encapsulate an ethics of conviction to a certain extent, problems and resistance arose when convictions changed the proscriptive ideal of a virtuous person. This was the case when convictions made one turn away from everyday responsibilities to one's neighbours and kin, which entailed a withdrawal from the virtuous exchanges that reproduced the ideals of dharma. I consider these instances of 'extra-ordinary ethics'.

The practice that reformist Islam agitated against most was shirk (religious mediation), including the worship of saints in shrines. Masiruddin and Wahed rejected their father's practice of mediation, and they instructed him that even though he could still welcome and advise both Hindus and Muslims at the shrine, he could no longer guarantee them the efficacy of his power (as the power is with Allah) and he was no longer allowed to accept money for his services. Masiruddin explained the disapproval of shirk as follows: Islam is like a complete system, like when rain falls and it evaporates and goes back to the sky to materialize in rain again. So, you can only directly worship Allah, not via a mediator.'

The shrine was moreover the central locus of a traditional system of patronage involving several celebrations the TJ opposes. The most significant was the celebration of Muharram. ${ }^{25}$ Deobandi Islam prescribed that Muslims should fast for two days on this auspicious day, as opposed to the traditional fighting with bamboo sticks, self-flagellation, and processions involving music and dance. The Khadims, most of whom were explicitly Deobandi and considered themselves to be more reformed, educated, and civilized, opposed the traditional celebration but grudgingly admitted that 'it has to be done because of the market'. In their capacity as caretakers (musualis) of the WAQF property, they had to invest a part of the profits in the

${ }^{25}$ Muharram is technically the first month of the Islamic calendar, but in common speech refers to the tenth day of this month. On this day, the Day of Ashura, Shia Muslims typically mourn over and replicate the sufferings of Hussain ibn Ali; Sunni Muslims usually fast in commemoration of Moses' victory over the Eqyptian pharaoh. The Muslims in my fieldsite are all Sunni, but the practice of Islam in West Bengal has historically included Shia as well as Sunni practices. 
celebration and provide the (blessed) food, musicians, and medical assistance. They feared that if they did not continue this form of patronage, the 'public'-the poor, 'uncivilized', and 'unreformed' Muslims in the village - would protest. Indeed, Joygramis from other hamlets who participated in the celebrations greatly enjoyed it and steadfastly maintained that they would not let the Khadims stop their stick fights. They attached significance to these fights because it was a tradition, a skill passed on from father to son for generations. It was just fun, not a matter of Islamic doctrine. Some did acknowledge that (in particular) the alcohol abuse involved was a deviation from dharma, but they considered this as an eccentricity that did not hamper their aspirations to be good Muslims or even modern subjects. For Wahed, on the contrary, it was a crucial matter of dharma. He was particularly upset about the sacrilegious practices and refused to contribute his share - which in turn incurred the wrath of the other Khadims. As a result of the objectification process typical of piety movements (Hirschkind 2006; Mahmood 2005; Keane 20I5: I99ff), Wahed embodied a new kind of agency and personal responsibility towards the Muslim ummah (community) as a whole, rather than to his immediate kin.

Besides shirk, any practices deemed Hindu were resolutely rejected. One of the most consequential acts was the rejection of dowry, as its exchange was fully integrated in village life. Customarily, the girl's family would pay a dowry to the groom's family, a tradition that had grown out of proportion, with lakhs of rupees (thousands of pounds), fridges, and bicycles being demanded from the new in-laws. Islamic law, however, opposes this practice, so the reformist Deobandis argued against it, calling it a 'bad Hindu influence'. Hickel (2015) has observed that the interruption of these kinds of life-cycle rituals is particularly liable to create a cultural backlash (cf. Keane 2015: 234-235). What is remarkable here is that the backlash was not against the interventions of a modern state seeking to civilize its citizens but against the Tablighis. This observation positions the TJ firmly as a catalyst of an alternative modernization that would run parallel to any modernization efforts of the state. Below, I recount in detail a conflict that occurred due to the withdrawal from a dowry exchange.

\section{Ethical interruption: a 'Jamaat' wedding}

On a fateful day during the month of Ramadan, Rahaman Saheb, the most authoritative Islamic scholar in Joygram, was sitting with his sons 
on the roadside, when their neighbours Kairul and his sisters and mother came up to them and started shouting abusive words ( $g \bar{a} l \bar{a} g \bar{a} l)$, even calling Rahaman Saheb a pig's son. This infuriated his sons who retaliated with physical violence. It was a shocking event: as madrasa teachers and imams, Rahaman Saheb's sons were supposed to be exemplars of pious behaviour. The conflict revolved around the marriage of Kairul's brother Azizul but was fundamentally about the reformist withdrawal from customary exchanges.

Azizul was a devout TJ participant and as such was very close to the sons of Rahaman Saheb who occasionally joined the TJ. Azizul married a girl against his mother's wishes (she opposed the marriage because the girl's family was very poor). So, while his mother was hoping Azizul would marry a wealthier girl and she would earn two lakhs by virtue of having a son, Azizul followed Islamic rule and married the girl he had fallen in love with, without any money being exchanged. The wedding had been small and sober, a proper Islamic wedding, Jammater biye as they would say. ${ }^{26}$ It had taken place only at the girl's house and not at both households, as is traditionally the case, and no food was distributed in the relevant neighbourhoods.

Azizul's family's fury was directed at Rahaman Saheb's family because Nasiruddin (Rahaman Saheb's eldest son) had taken Azizul to meet the girl. In addition, imam Jamiruddin (Rahaman Saheb's second eldest son) had married the couple, but, Jamiruddin claimed, only after it was uniformly approved during a local meeting of the TJ.

Mediated by Basir Khadim in his capacity as representative of the political party in power, the two families eventually reconciled. They remained mutually hostile for the remainder of my fieldwork, however, and Kairul's anger did not wane. Months later, I prompted him to tell me why he and his mother had been so upset with the marriage. First, he said, 'my mom didn't even see her face! And how can he choose a wife my mom hasn't even seen yet!' Then he pointed to the shack behind us: 'Their house is like that. They can't offer their guests anything, not even a place to sit, not even a tea. They can't offer any respect.' Then, of course, there was the dowry. Already, he explained, Azizul had gotten in trouble. His affines had urged the couple to leave the house, because they did not have the means to sustain them. Azizul's wife was pregnant but Azizul had hardly any income-he

\footnotetext{
${ }^{26}$ Biye means 'wedding' and jāmāter refers to the Tablighi Jamaat, which in fact means it is a wedding according to the prescripts of the Deoband school of thought.
} 
worked occasionally at the cattle market - and was not able to provide his wife and baby with either a house or food.

If he would have gotten a dowry, he could have started a small business, invest the money somehow and have a regular income. But he didn't think about it, that when you need 50 rupees to feed one person, you need ioo for two people and 150 for three people. Think of the price of tomatoes, $20 \mathrm{~kg}$, or potatoes, Io kg, there are so many costs involved in feeding a family. But now he realizes, now he has come back home because he isn't fed there, and he walks in like a dog with his tail in between his legs, eats, and walks out like a dog again.

Kairul displayed a sinister smile. 'And they [Rahaman Saheb's family] will also understand that they made a mistake, that you shouldn't create trouble in other people's family. Now that Azizul is in big trouble, they will all realize; they made a mistake.'

\section{'Extra-ordinary ethics': changes in personhood and relatedness}

An analysis of the tension between villagers and relatives as an example of 'extra-ordinary ethics' reveals deeper currents of change more than exclusive attention to pragmatic motivations would do. The withdrawal from traditional exchange practices could be interpreted as a move towards an individualistic economy disembedded from local exchanges. In particular, changes in life-cycle rituals may signify a new kind of individual freedom, exempt from the demands and costs of traditional exchange relationships (Horstmann 2007; Janson 2013) and expensive patronage such as is expected on the festival of Muharram. The TJ's official doctrine condemns the materialism they associate with Western modernity and opposes conspicuous consumption (cf. Masud 200ob: xxix), but reformist Islam does not condemn material pursuits per se, and individual TJ participants may find ways to combine piety with prosperity. Individual prosperity may be included in a broader ethical narrative: among reformist Muslims elsewhere economic success can be considered a virtuous act that is part of the production of the 'proper' Muslim (Osella and Osella 2009; Rudnyckyj 2009), similar to some expressions of revitalized and charismatic Christianity (Coleman 2000; Comaroff 2008). The rejection of the dowry in particular may also be an instance of enacting male virtue and male supremacy. Azizul embodied a new kind of modern, virtuous masculinity - not unreflexively following habitual practices but enacting personal 
responsibility, agency, and choice, and answerable to the virtuous Muslim community (embodied in the local TJ meeting) rather than to kin. Moreover, most villagers were aware that dowry practices were no longer legally allowed. By rejecting the dowry in a TJ meeting, Azizul and the others involved may have been appropriating a secular legal ruling (possibly demanded by secular feminists) as a TJ ruling enacted by modern, Islamic, and virtuous males.

I do not want to romanticize the motivations for change or underplay the pragmatism involved. It may be true that for some of the wealthier participants in Joygram, reformist Islam offered a 'social framework that legitimises the pursuit of individualised lifestyles' (Janson 2013: 263) and enabled displays of male virtuosity. However, whether as explicit motivation or an implicit consequence, there were more complex ethical transitions.

For many Joygramis, it was a sense of moral failure that impelled them to cultivate piety. Yet they were not sure how to combine this with everyday demands, which brings me again to the householder's dilemma. Some Tablighis and devout Deobandis aimed for a level of Salvationist asceticism, and the seasonal and annual travels of the Tablighis offered them a space for temporary renunciation (cf. Masud 200ob: xviii). However, at home they could not entirely escape 'the social world of interdependence and relationships of exchange' (Parry I994: 269). Kairul made it very clear that Azizul had disregarded not only his mother's authority, but also the normative relationships of exchange. ${ }^{27}$ In his account of the story, Kairul sounded very pragmatic: the disregard of the ways in which material or monetary goods and services were customarily exchanged risked the survival and reproduction of the household. Azizul himself, and the Tablighis who supported him, may have been closer to salvation in their renunciation of 'the social world of interdependence', but they put Azizul's mother in a situation where survival rather than salvation was the main worry. In this light, Azizul could be considered selfish and individualistic.

However, the seemingly disproportionate outrage of Kairul's family points to a deeper issue which comes closer to Parry's observation that 'salvation turns its back on society and disregards its basic axioms'

${ }^{27}$ The dowry is not a timeless practice of exchange: oral history tells that in pre-partition, Muslim- majority Bengal there was a variety of practices, including bride's price (as practised in predominantly Islamic places such as Khasmir, according to my participants) or no dowry. 
(Parry 1994: 269). Joygrami Muslims embraced a type of ethics that is best understood as a virtue ethics, one that was visceral rather than interiorized and was strongly related to the local ethics of bio-moral exchange. The 'good human person' is morally and physically generated from exchange relationships with the creator-god and social networks. The goal of virtue ethics is ideally not an abstract utopia (as is the case with an ethics of conviction). Reciprocal exchange itself is the source of well-being and productiveness (cf. Parry 1986: 465) and, as such, the enactment of virtue and the 'art of life'-living ethically for the sake of it, which implies the transcendence of instrumentality (Lambek 20I0: 23). The withdrawal from reciprocal exchange is an act of disregard for the cosmopolitics of bio-moral exchange and therefore threatens the social regeneration of ethical persons. Without the customary exchange of food in the village, the bride was not incorporated within the network of social relatedness, which is essential for sustaining order, dharma.

Reformism is by implication a reconfiguration of what is considered virtuous. If dharma is the potential of an ethics of order and justice, then reformism not only re-establishes order but also reconfigures how the potential for order and justice can be realized. It centralizes a different kind of person, one who is generated by the individual pursuit of ethical transformation embedded in the larger Islamic ummah rather than through interactions within local and kin relatedness. Whereas the 'monadic modern person' and the 'discontinuous personage' (Lambek 2013) were both already valid constructs in Joygrami cosmopolitics, the relative salience was shifting in favour of the continuous modern person. In the process of objectification, rationalization, and individualization, the ideology of the discontinuous, protean person was losing significance. Even though salvation was possibly more important for the reformists, they did not neglect this-worldly virtue. However, the locus of virtue became the individual and the Islamic ummah rather than relatedness within the village. As in other expressions of a modern ethics of conviction, 'being ethically good and sincere in one's care for the "neighbour" [was] in this view of no real consequence if not embedded in a larger vision of transformation' (Hansen 2009: i6). In their desire to transform their society into a properly Islamic one, and in their yearning for salvation, Azizul, Nasiruddin, and Jamiruddin disregarded their care for their relationships within the village, just as Wahed disregarded both the people of other hamlets who were denied his contribution to Muharram and solidarity with the other Khadims.

The Tablighis were mainly opposed to practices that might have been influenced by Hinduism, even when some, strictly speaking, might have 
had nothing to do with Hinduism but were called 'Hindu' because the prevalent culture is associated with the dominant majority. They would usually give an extended justification as to why this 'Hindu' practice was not virtuous, whereas the Islamic practice was virtuous, with reference to science or to the ways in which traditional practices are inappropriate in current social and economic conditions. The reformists would say that they preferred a small and inexpensive, one-day Islamic wedding as opposed to several days of reciprocal meals and celebrations which the villagers simply could not afford, and that they opposed the dowry because it is exploitative.

In this light, the TJ in Joygram not (only) opposed practices because they had a different conception of virtue, but (also) because those practices were actually - upon reflection - no longer considered virtuous within their own ideological frame. Ideally, reciprocal exchanges would take place between equals - perhaps not equals in wealth and power but certainly in dignity and fundamental human value. There was an implicit recognition among the reformist Muslims that the staggering inequality in wealth and power within Joygram was eroding the equality between people and that the exchanges had become instrumentalized and disembedded from dharma. Material inequality is not necessarily problematic per se, but it is if it erodes the principle of equal human dignity. This was very clear in the case of Muharram. As the power of Abu Bakr as a spiritual leader was slowly eroding, Haji Saheb, the boss of the cattle market, and the other shareholders were increasingly taking charge of ritual patronage. ${ }^{28}$ The result was an increasingly instrumentalized patronage, depleted of spiritual meaning, and deeply corrupted at that. Everyone in Joygram was aware that the shareholders kept a double account and that most of the profits that on paper were set aside for 'charitable funds' would disappear directly into the shareholders' pockets. ${ }^{29}$ What the reformists aimed to instantiate once again was the central Islamic principle of equality. And they did so particularly in instances where modern institutions (particularly the capitalist market) had corrupted the nature of those exchange to the extent that they no longer represented the ethics they were supposed to perform: Islamic values of equality and solidarity. In attempting to

${ }^{28}$ Abu Bakr had fought a I5-year court case with Haji Saheb over who was the designated caretaker (musuali) of the WAQF property. He lost, and only retained the rights over the shrine and a small part of the cattle market.

${ }^{29}$ The musualis had to provide official accounts to the State WAQF board. They did not have to pay tax on the profits set aside for charity funds. 
transform those practices, Tablighis were re-establishing the Islamic value of equality, but now between autonomous individuals, at the expense of the customary regeneration of persons through exchange.

The irony is that when exchange is not between equals, some can opt out whereas others are dependent on it. The rich were more likely to be Deobandi and to refuse to engage in exchange practices. Azizul was not at all wealthy and could not afford to be independent of exchange relationships. For this reason, I suggest, Kairul was deeply upset about the fate of his brother: he made a mistake that may prove to have grave consequences.

In light of this analysis, the violent conflict over Azizul's wedding (as well as the fear of conflict over the end of Muharram) was an instance of 'extra-ordinary ethics':

$[\mathrm{T}]$ he 'ordinary' implies an ethics that is relatively tacit, grounded in agreement rather than rule, in practice rather than knowledge or belief, and happening without calling undue attention to itself. When, by contrast, ethics does become explicit, that is generally (I) in respect to its breaches; (2) with regard to ethical problems or issues in which the right thing to do is unknown or hotly contested; (3) in prophetic movements and social or ethical renewal; and (4) among priestly classes attempting to rationalize and educate (Lambek 20I0: 2).

In this case, the right thing to do was hotly contested, because of a movement of ethical renewal that was attempting to rationalize uneducated Muslims. In a time of conversion, ethical transformation, or ethical breach - those moments when ethics become explicit- the contradictions and compromises with which one lives - and always have and always will-come to the surface (Engelke 2004; Janson 2015; Robbins 2004). That is, I am not arguing that reformism is an invasion in a coherent cultural system (see Osella and Osella 2008) or a complete 'break with the past' (see Meyer 1998). At this moment of 'extra-ordinary ethics', the reformists continued to act within a virtue ethics of order and justice, but they did not attach the same significance to social exchanges. And this heralded the transition to a different way of being in the world, less embedded in local community, and both more modern and more anti-modern in outlook.

\section{Seeking civility and inclusion through culture}

As is clear from his narrative, Masiruddin had a strong desire to 'uplift' his community. Being a 'bad Muslim' was tightly bound up with the idea that 
Muslims lacked adequate 'culture' (used in English). In the view of the reformists, improving culture by becoming a better Muslim should make them more likely to be included in the Indian nation-state. The Tablighis wanted to show, through their aesthetic performance and virtuous conduct, particularly in an atmosphere of suspicion, that Muslims were peaceful, generous, and modest. However, their Islamic aesthetics further classified them as Other, not indigenous to Indian soil.

Muslims were acutely aware that they had to cultivate themselves as a particular kind of modern Muslim citizen in order to make demands on the state. The pervasive idea is that one has to make oneself an asset to the nation and live lawfully before one can gain this recognition. Deobandi-trained imams or TJ members indirectly encompassed Indian law in the Islamic normativity as they would profess that it would be a sin to not obey Indian law, and disobedience of the law would have consequences for the afterlife. ${ }^{30}$

The reformists' aspiration for modern subjectivity did not imply a wholesale co-opting of the modernity of the state. Their tactics were partly pragmatic, to gain not only dignity and respect, but also access to state services and employment, and protection against (violent) discrimination. Relegated to the margins of the nation-state, they had to constantly reassert their allegiance. Williams (2012) found that in Varanasi, Muslims actively engaged with the rhetoric of secularism because it offered spaces of recognition and participation in the face of majoritarian discriminatory practices. In Joygram, as in Varanasi, 'being a 'good Muslim' and a 'good Indian citizen' went hand in hand and it was 'by emphasising the latter that [Muslims sought] to realise justice and the public recognition of the former ... Muslim citizenship is negotiated through a particular way of being in society that reflects forms of civility, connection and inclusion' (ibid.: 989-99I).

In Joygram, the idiom used to encompass modern civility as well as Islamic moral righteousness was often the all-encompassing concept of culture, which was locally infused with Islamic connotations. Islamic reformism became a salient vehicle through which to cultivate the rational, reflexive subjectivity that allowed for the inclusion of Muslims in the civilized citizenry. Education was considered crucial for learning

${ }^{30}$ A mufti (Islamic legal scholar) at the Deoband madrasa I spoke to at the TJ headquarters in Delhi confirmed that 'it is a sin not to obey the law of the country where a Muslim lives'. Even travelling on a bus without a ticket is a great sin (Urdu guna) and would cost 'forty days good work' in the accounting system for the afterlife. 
culture, and for Muslims inspired by reformism, Islamic education in particular would cultivate culture, which included the inculcation of civility. In other words, the 'way of being' that reflects civility was Islamic; for this reason, a government madrasa or a mission school was a vehicle through which to embed a culture that was considered not fundamentally different to the culture inculcated in the Indian citizenry by national leaders. Similarly, the rhetoric around the mission schools focused on the idea of 'good culture' (bhālo culture) in the ambition to include Muslims in the (respectable) Indian citizenry.

The idea that culture provides the moral backbone to the project of the Indian nation-state is, at first glance, a seamless reproduction of the 'anti-politics discourse' (Hansen I999, 2000) which is rooted in the paradox of Indian secularism. In India, the secular polity is premised on religious pluralism rather than absence of religion and entails the creation and management of discrete pre-political religious communities by a supposedly neutral and 'enlightened' state whose very legitimacy is derived from their control of the potentially dangerous 'masses'. Meanwhile, moral projects are the responsibility of these religious communities, which supposedly remain unspoiled by politics and the economy. The communities, indeed, have to foster 'good culture'.

However, the idiom of culture, when employed by my interlocutors, was infused with not only Islamic content but also with aspirations for modern personhood and had the connotation of infusing the morally corrupted domains of politics and the economy with cultured, ethical content. That is, 'culture' in the anti-political discourse has a different meaning from culture in the Joygrami discourse. The paradoxes of the Muharram celebrations highlight the problem of this disjunction.

The State WAQF Board was one of the institutions that continued the post-colonial policy of anti-politics, as it was based on the assumption that Indian Muslims formed a static, coherent, and unpolitical cultural community (Hansen 2000: 269). Through such institutions, as well as through state-funded 'secular' madrasas, the responsibility to 'control' the 'irrational masses' was delegated to the civilized leaders of the community. Although Muharram may have been hollowed out of

\footnotetext{
${ }^{31}$ For a more nuanced and complex rendering of the secularism of the Indian state, see Pool 2016. At the time of writing (2018) Hindu-nationalist politics seems to be increasingly hollowing out the secularism of the Indian polity. This analysis is still relevant, in my view, if in an exacerbated form, as the 'enlightened' state increasingly obviously co-opts the moral project of the supposedly unspoiled Hindu community and still gains legitimacy from controlling the dangerous (Muslim) masses.
} 
spiritual meaning and become a means of profitable tax avoidance and a display of power inequality, on the surface it looked like the timeless celebration of Indian syncretic culture.

Through such institutions, Muslims were 'thrown back' into a supposedly unified, 'elevated unpolitical cultural community based on the values of the Koran, Hadith and the Personal Law' (Hansen 2000: 269). The irony of Muharram was that it was Indian law that inevitably drew the shareholders of the cattle market back into the practice of 'traditional' ritual patronage. The other villagers participated in the celebrations because it was 'fun', not because of its religious value, and it came to signify an aberration in their aspirations for good culture and a civilized, reformed lifestyle.

The complexity of the Muharram celebrations demonstrates that in reality there never was a negotiation 'between reified cultural communities with fully formed notions of morality and public ethics and a state driven by "reason"" (Hansen 2000: 269). I want to highlight two points in this regard. First, culture is not static, reified, and community-bound; for my interlocutors the concept implied both modern, passionate convictions as well as socially generated, embodied ethics. Secondly, good culture became a vehicle for demands to be included in the civilized citizenry. Improving culture meant civilizing and governing oneself 'in morality as well as law ... as befits the citizen of a secular, liberal society' (Asad 2003: 226). So, whereas Hansen (2000: 264) argues that the TJ, like other cultural-religious organizations, is ultimately inward looking and informed by 'anti-political notions of purification of the community', I suggest that it could equally function as a vehicle for the outward-looking aspiration to cultivate modern civility, but with the anti-modern propensities of social relatedness and holistic ethical ambitions. Joygramis felt that current politics was run by uncultured 'animals' (perhaps the ideal 'free individual' of modern liberalism but lacking in social responsibility) and needed to be restored with culture-embedded dharma. ${ }^{32}$ In Joygram, the TJ became a form of 'anti-politics' that reproduced the bifurcated framework of 'dirty' politics and 'clean' Islam. Its message was more introspective than the passionate convictions described by Hansen (2009) and Comaroff (2008) because of its limited space of navigation, but that was not the

\footnotetext{
${ }^{32}$ As such, they are remarkably similar to the anti-liberal South African migrants Hickel (2015: I3) talks about, and to many other right-wing and religious social movements reacting against cultural globalization (Meyer and Geschiere 1999).
} 
motivation for most of the (rural) participants; in fact, it curtailed their intentions for holistic renewal.

Dharma is not an internally static, primordial element of sociality but changes with the demands of modern life. The vernacularization of modern categories impinged on new understandings of dharma, namely, as religion in the narrow sense. Dharma can denote an ethics of justice and order that is not limited to an explicitly religious normativity. Good politics, rooted in dharma, does not necessarily mean Islamic politics. Even if it transpired from conversations that, for my interlocutors, dharma could mean an ethics of justice in a much broader sense, these synthesized discourses were aesthetically, rhetorically, and practically shaped according to an Islamic reformist discourse because Joygramis had also vernacularized the idea of dharma-as-religion. In fact, Islamic reformism in Joygram is an inherently ambiguous response to the modern categorization and objectification of dharma as 'religion'. It is a non-political, rationalized, and individualized expression of dharma that contains the potential for holistic ethical renewal by making Islam a 'total way of life' that fits within the global Islamic reformist agenda. The desire to imbue all spheres of life-political and economic, public and private - with ethical content, starting with individual self-fashioning, was absolutely central to the Tablighis' project in Joygram. So while modern categorization might relegate religion to the private sphere, the comprehensive project of pious self-cultivation renders the private both sacred and political, giving religion a new, comprehensive meaning. ${ }^{33}$ This project did not imply disregard of all secular liberal values (it incorporates many of those values), but did imply protesting against the idea that there can be morally neutral social domains, because experience had proven its drawbacks. Moreover, in Joygram, secularism, both the English term and the vernacular dharmaniropekșata, was not understood in opposition to religion or dharma, but as the principle of non-discrimination as well as harmonious coexistence. Citizens and politicians were expected to derive their ethical potential from dharma, including the propensity for peaceful pluralism.

${ }^{33}$ Compare with White's (2012: 1458) observation, on the basis of research undertaken with Muslims and Hindus in Bangladesh, that 'just as modernization reassigns religion to the personal sphere, so it also constitutes "the personal" as a primary arena of governance, discipline, and satisfaction' so that what appears 'to be the marginalization of religion, thus brings with it simultaneously a re-discovery of and re-emphasis upon it'. 


\section{Post-secular Islamic reformism?}

Metcalf (2002) has suggested that the Tablighi, living his everyday life in society, can be constructed as secular because of the private, interiorized, and individualized character of his religious practice. The TJ, because of what is perceived as its political 'quietism', may indeed 'mesh' better in secular polities, such as South Africa (Moosa 2000: 22I; cf. Kepel 1997), European countries, and India, than other explicitly political Islamic organizations. Yet, I think that the situation is not only more complicated, but also that calling the TJ 'secular' or even apolitical is problematic as this is a normative statement that already assumes different domains in society. Therefore, this categorization fails to capture the complexity of the motivations and experiences of Joygrami Tablighis, who were informed both by a specific local cosmopolitics that defied such a separation of domains, as well as by globally circulating ideals. Although I have so far called my interlocutors both modern and anti-modern, they are perhaps better called post-secular or post-liberal ${ }^{34}$ in that they were familiar with modern secular and liberal ideologies but went beyond them in their motivations and aspirations. Reformist Islam should not be misunderstood as pre-modern, anti-secular, or secular because it encompasses those ideologies in vernacularized forms on the basis of a different ideal conception of society. The practices of the $\mathrm{TJ}$ in Joygram challenged an ordering of modern society into sacred and secular spaces, with secular politics and a market economy disembedded from the moral realm. The paradoxical tension that remains is not exclusive to the $\mathrm{TJ}$ in Joygram, but may be germane to piety movements elsewhere, because, as Keane (2015: 215) observes, 'the totalising pressure towards the full integration of pious personhood appears to stem, in part, from the very distinction between religion and nonreligion it seeks to overcome'.

Moreover, Islamic-inspired aesthetics and culture may not increase their access to a public sphere increasingly dominated by the Hindu majority. The traditional Islamic scholars in Joygram, already used to a suspicious gaze, were aware of the marginalization-rather than respect - that the carefully groomed aesthetic subjectivity of the reformists would bring them: 'the rule of the government is: don't give anything to the ones with tupis and beards' (sarkārer 'rule' hacche: tupi- dāri-oyālāke kichu nā dite).

${ }^{34}$ See Milbank and Pabst (2016) on post-liberalism. 


\section{Conclusion}

Joygrami Muslims were caught in various irreconcilable oppositions: the educated bhadralok versus the uneducated Muslim; the indigenous Hindu versus the disloyal Muslim; the pious (Arabic) Muslim versus the wicked (Bengali) Muslim; and the ascetic, civilized, and rational Muslim Joygrami versus the poor, uncivilized, and 'stupid' Muslim Joygrami. The cultivation of a pious self could only overcome some of these oppositions and would reproduce other oppositions. Moreover, the various forms of marginalization had become inherent to racialized and (de-)moralized identifications. Even if the politico-economic and social marginalization could not be undone that easily, the practice of self-renewal itself recovered a sense of dignity and self-worth. The sense of marginalization and the involvement with morally degrading political and economic practices had detached Muslims from their moral dignity and ethical autonomy. The TJ offered the opportunity for the personal construction of an ethical narrative. All Muslims, and not only those who have access to the bhadralok spaces of education and 'civilization', had the potential to reform and to transcend above their older 'inferior' self.

The growing popularity of the Tablighi Jamaat in Joygram marked a moment of intense cultural, political, and moral transition and contestation. It has been my intention to embed Islamic reformism in the political economy in which it is situated, to avoid an exoticizing and essentializing interpretation of this historical transition as a narrow religious change, somehow outside the modern world. A presentation of the Tablighi Jamaat as it was practised, performed, and talked about shows the complexity of this moral project, which defies being simplistically categorized as within or against pre-modernity.

The difficulty of categorization is obvious in the ambivalent ways in which Tablighis interacted with traditional patronage between the nearby hamlets and reciprocal exchange between households, seeking to transform while nonetheless becoming embroiled in these exchanges. Although the Tablighis' practices incited a backlash against their performance of a modern mode of being, their actions also reflected a discontent with the ways in which modernity had already corrupted customary exchange. Other studies have pointed out that the alternative modes of being in the world that Islamic reformism introduces has locally salient political effects, contesting intergenerational (Janson 2013), gendered (Amrullah 20II; Jasani 20I3; Nisa 20I4), and class power structures (Sikand 2002). This article demonstrates, first, that contestations do not remain superficially political but rather have a deep impact on 
very fundamental questions of righteous living, and I therefore call these instances of 'extra-ordinary ethics'. Secondly, the changes do not only move from the traditional to the modern but also against the modern towards a different ideal society. This observation emphasizes the complexity of people's relationships to modern attitudes and values.

The alternative modernity Tablighis enact is premised on key notions of personhood and justice. Unlike the radically free human of modern liberalism, freedom in Joygram is limited by dharma: the Joygrami Muslim person gains individual freedom and ethical autonomy only after the social generation of the 'human person' and submission to the creator-god. Dharma may change within but continues to be the source of ethics in all spheres of life, which includes secular (plural) life in the modern world, especially when other sources of moral fabric seem absent in an increasingly individualized, fragmented, and corrupted society. However, if modern states and political categorizations continue to exclude such alternative notions of society, then they will continue to exclude Islamic reformism - and other ethical, revivalist, and social movements that are not simply modern or anti-modern, but post-secular or post-liberal in nature.

\section{References}

Ahmad, I. 2009. Islamism and democracy in India. The transformation of Jamaat-e-Islami. Princeton: Princeton University Press.

Ahmad, I. and H. Reifeld (eds) 2004. Lived Islam in South Asia: Adaptation, accommodation, and conflict. Delhi: Oxford University Press.

Ahmed, C. 2008. Introduction to special issue: Performing Islamic revival in Africa. Africa Today, 54(4), pp. vii-xiii.

Ahmed, R. 1981. The Bengal Muslims I87I-1906. Oxford: Oxford University Press.

Ali, J. 2003. Islamic revivalism: The case of the Tablighi Jamaat. Fournal of Muslim Minority Affairs, 23(I), pp. I73-I8I.

Amrullah, E. F. 20II. Seeking sanctuary in 'the age of disorder': Women in contemporary Tablighi Jamā'at. Contemporary Islam, 5(2), pp. 135-160.

Asad, T. 2003. Formations of the secular: Christianity, Islam, modernity. Stanford: Stanford University Press. Berman, M. 1982. All that is solid melts into air. The experience of modernity. New York: Penguin Books. Burghart, R. 1983. Renunciation in the religious traditions of South Asia. Man, pp. 635-653.

Chatterji, J. 2007. The spoils of partition: Bengal and India, 1947-1967. Cambridge: Cambridge University Press.

Chatterjee, P. 2009. The coming crisis in West Bengal. Economic and Political Weekly, 44(9), pp. $4^{2-45}$.

Cohn, B. S. 1987. An anthropologist among the historians and other essays. Delhi: Oxford University Press.

Coleman, S. 2000. The globalisation of charismatic Christianity, Vol. 12. New York: Cambridge University Press. 
Comaroff, J. 2008. Uncool passion: Nietzsche meets the Pentecostals. Paper presented at the Max Weber Lecture Series, European University Institute.

Das, V. 20I0. Moral and spiritual striving in the everyday: To be a Muslim in contemporary India. In A. Pandian and A. Daud (eds), Ethical life in South Asia. Bloomington: Indiana University Press, pp. 232-252.

- 2014. Ethics, the householder's dilemma, and the difficulty of reality. HAU: Fournal of Ethnographic Theory, 4(I), pp. 487-495. http://dx.doi.org/Io.I4318/hau4.I.03I, [accessed 4 February 2020].

Deeb, L. 2006. An enchanted modern: Gender and public piety in Shi'i Lebanon. Princeton: Princeton University Press.

Dirks, N. 200r. Castes of mind: Colonialism and the making of modern India. Princeton: Princeton University Press.

Eaton, R. 1996. The rise of Islam and the Bengal frontier I204-I706. Berkeley: University of California Press.

Eickelman, D. F. 1992. Mass higher education and the religious imagination in contemporary Arab societies. American Ethnologist, I9(4), pp. 643-655.

Eickelman, D. F. and J. W. Anderson (eds) 1999. New media in the Muslim world: The emerging public sphere. Bloomington: Indiana University Press.

Eickelman, D. F. and J. Piscatori 1996. Muslim politics. Princeton: Princeton University Press.

Eisenstadt, S. N. 200o. Multiple modernities. Daedalus, I29(I), pp. I-29.

Engelke, M. 2004. Discontinuity and the discourse of conversion. Fournal of Religion in Africa, 34(I), pp. 82-I09.

Giddens, A. 1990. The consequences of modernity. Stanford: Stanford University Press.

Grosso, S. 2013. Extraordinary ethics: An ethnographic study of marriage and divorce in Ben Ali's Tunisia, PhD thesis, London School of Economics and Political Science.

Gupta, N. 2009. Reading with Allah: Madrasas in West Bengal. Delhi: Routledge.

Haniffa, F. 2008. Piety as politics amongst Muslim women in contemporary Sri Lanka. Modern Asian Studies, 42(2-3), pp. 347-375.

Hansen, T. B. 1999. The saffron wave: Democracy and Hindu nationalism in modern India. Princeton: Princeton University Press.

2000. Predicaments of secularism: Muslim identities and politics in Mumbai. Fournal of the Royal Anthropological Institute, 6(2), pp. 255-272.

2009. Cool passion: The political theology of conviction. Amsterdam: Amsterdam University Press.

Hickel, J. 2015. Democracy as death. The moral order of anti-liberal politics in South Africa. Berkeley: University of California Press.

Hirschkind, G. 2006. The ethical soundscape: Cassette sermons and Islamic counterpublics. New York: Columbia University Press.

Horstmann, A. 2007. The inculturation of a transnational Islamic missionary movement: Tablighi Jamaat al-Dawa and Muslim society in southern Thailand. Sojourn: Fournal of Social Issues in Southeast Asia, 22(I), pp. 107-I30.

Huq, M. 2008. Reading the Qur'an in Bangladesh: The politics of 'belief' among Islamist women. Modern Asian Studies, 42(2-3), pp. 457-488.

2009. Talking jihad and piety: Reformist exertions among Islamist women in Bangladesh. Journal of the Royal Anthropological Institute, ${ }_{5} 5\left(\mathrm{~S}_{1}\right), \mathrm{S}_{1} 6_{3}-\mathrm{S}_{1} 82$.

Iqtidar, H. 20II. Secularizing Islamists? Fama'at-e-Islami and Jama'at-ud-da'wa in urban Pakistan. Chicago: University of Chicago Press.

Jalais, A. 2010. Forest of tigers. People, politics and environment in the Sundarbans. Delhi: Routledge.

Jamal, A. 2013. Famaat-e-Islami women in Pakistan. Vanguard of a new modernity. Syracuse, NY: Syracuse University Press. 
Janson, M. 2013. Islam, youth and modernity in the Gambia: The Tablighi Jama'at. New York: Cambridge University Press.

20r6. 'How, for God's sake, can I be a good Muslim?': Gambian youth in search of a moral lifestyle. Ethnography, I7(I), pp. I-25.

Jasani, R. 2013. Violence, reconstruction and Islamic reform. In F. Osella and C. Osella (eds), Islamic reform in South Asia. Delhi: Cambridge University Press, pp. 255-280.

Keane, W. 2007. Christian moderns. Freedom and fetish in the mission encounter. Berkeley: University of California Press.

2015. Ethical life: Its natural and social histories. Princeton: Princeton University Press.

Kepel, G. 1997. Allah in the West: Islamic movements in America and Europe. Stanford: Stanford University Press.

Laidlaw, J. 1995. Riches and renunciation: Religion, economy, and society among the fains. Oxford: Clarendon Press.

2014. The subject of virtue: An anthropology of ethics and freedom. Cambridge: Cambridge University Press.

Lambek, M. 2010. Introduction. In M. Lambek (ed.), Ordinary ethics: Anthropology, language, and action. New York: Fordham University Press, pp. I-38.

2013. The continuous and discontinuous person: Two dimensions of ethical life. Journal of the Royal Anthropological Institute, I9(4), pp. 837-858.

Luhrmann, T. M. 2012. When God talks back: Understanding the American evangelical relationship with God. New York: Vintage Press.

Madan, T. N. 1982. Way of life: King, householder, renouncer. Essays in honour of Louis Dumont. Delhi: Motilal Banarsidass Publisher.

Mahmood, S. 2005. Politics of piety: The Islamic revival and the feminist subject. Princeton: Princeton University Press.

Masud, M. K. (ed.) 200oa. Travellers in faith: Studies of the Tablīghī Jamā'at as a transnational Islamic movement for faith renewal. Leiden: Brill.

_ 200ob. Introduction. In M. K. Masud (ed.), Travellers in faith: Studies of the Tablīghī Jamā' at as a transnational Islamic movement for faith renewal. Leiden: Brill, pp. xiii-xxxix.

Metcalf, B. D. I989. Islamic revival in British India. Deoband: I86o-19oo. Delhi: Oxford University Press.

— 1993. Living Hadīth in the Tablīghī Jama'āt. The Gournal of Asian Studies, 52(o3), pp. 584-608.

2002. Traditionalist Islamic activism. Deoband, Tablighis and Talibs. ISIM Papers IV. International Institute for the Study of Islam in the Modern World. Leiden: ISIM.

2003. Travellers' tales in the Tablighi Jamaat. The ANNALS of the American Academy of Political and Social Science, 588(I), pp. 136-I48.

Meyer, B. I998. 'Make a complete break with the past'. Memory and post-colonial modernity in Ghanaian Pentecostalist discourse. Fournal of Religion in Africa, 28(3), pp. 316-349.

Meyer, B. and P. Geschiere (eds) 1999. Globalization and identity: Dialectics of flow and closure. Malden: Blackwell Publishing.

Milbank, J. and A. Pabst 20I6. The politics of virtue: Post-liberalism and the human future. London: Rowman and Littlefield International.

Miller, M. L. 20I0. Slaves to fashion: Black dandyism and the styling of black diasporic identity. Durham: Duke University Press.

Moosa, E. 2000. 'Worlds' apart': Tablighi Jama'at in South Africa under apartheid, I963-1993. In M. K. Masud (ed.), Travellers in faith: Studies of the Tablighi Fama'at as transnational Islamic movement for faith renewal. Leiden: Brill, pp. 206-22I. 
Nisa, E. F. 20I4. Insights into the lives of Indonesian female Tablighi Jama'at. Modern Asian Studies, 48(02), pp. 468-491.

Noor, F. A. 20I4. The Tablighi Jamaat in West Papua, Indonesia: The impact of a lay missionary movement in a plural multi-religious and multi-ethnic setting. In J. Finucane and R. Michael Feener (eds), Proselytizing and the limits of religious pluralism in contemporary Asia. Kuala Lumpur: ARI Springer Asia Series, Vol. 4, pp. 65-80.

Osella, F. and C. Osella 2008. Introduction: Islamic reformism in South Asia. Modern Asian Studies, $42(2-3)$, pp. $247^{-257}$.

2009. Muslim entrepreneurs in public life between India and the Gulf: Making good and doing good. Fournal of the Royal Anthropological Institute, ${ }_{5}\left(\mathrm{~S}_{\mathrm{I}}\right), \mathrm{S}_{202}-\mathrm{S}_{22 \mathrm{I}}$.

- (eds) 2013. Islamic reform in South Asia. Delhi: Cambridge University Press.

Parry, J. I986. The gift, the Indian gift and the 'Indian gift'. Man, 2I(3), pp. 453-473.

— 1994. Death in Banaras. Cambridge: Cambridge University Press.

Pieri, Z. P. 2015. Tablighi Famaat and the quest for the London mega mosque: Continuity and change. New York: Palgrave Macmillan.

Pool, F. W. 20i6. The ethical life of Muslims in secular India: Islamic reformism in West Bengal, $\mathrm{PhD}$ thesis, London School of Economics and Political Science.

Robbins, J. 2004. Becoming sinners: Christianity and moral torment in a Papua New Guinea society, Vol. 4. Berkeley: University of California Press.

Robinson, F. 2008. Islamic reform and modernities in South Asia. Modern Asian Studies, 42(2-3), pp. 259-28I.

Rudnyckyj, D. 2009. Spiritual economies: Islam and neoliberalism in contemporary Indonesia. Cultural anthropology, 24(I), pp. I04-I4I.

Sachar Committee 2006. Sachar Committee Report: Social, economic and educational status of the Muslim community in India. New Delhi: Government of India, Cabinet Secretariat, Report of the Prime Minister's High Level Committee. Available at: http://www.minorityaffairs. gov.in/reports/sachar-committee-report, [accessed 25 February 2020].

Shehabuddin, E. 2008. Jamaat-i-Islami in Bangladesh: Women, democracy, and the transformation of Islamist politics. Modern Asian Studies, 42 (2-3), pp. 577-6o3.

Siddiqi, B. 2012. Reconfiguring the gender relation: The case of the Tablighi Jamaat in Bangladesh. Culture and Religion, I3(2), pp. I77-192.

Sikand, Y. 2002. The origins and development of the Tablighi Jama'at, 1920-2000: A cross country comparative study. Telangana: Orient BlackSwan.

Stacey, T. 2018. Myth and solidarity in the modern world. Beyond religious and political division. London: Routledge.

Starrett, G. 1998. Putting Islam to work: Education, politics, and religious transformation in Egypt. Berkeley: University of California Press.

Tarlo, E. and A. Moors 2013. Islamic fashion and anti-fashion: New perspectives from Europe and North America. London: Bloomsbury.

Taylor, C. I989. Sources of the self: The making of the modern identity. Cambridge: Harvard University Press.

2004. Modern social imaginaries. Durham: Duke University Press.

White, S. C. 2012. Beyond the paradox: Religion, family, and modernity in contemporary Bangladesh. Modern Asian Studies, 46(5), pp. I429-I458.

Williams, P. 2012. India's Muslims, lived secularism and realising citizenship. Citizenship Studies, I6(8), pp. 979-995. 